\title{
MELON CULTIVATION IRRIGATED WITH SALINE WATERS PROMOTE CHEMICAL ALTERATIONS IN AN ACRISOL
}

\author{
CULTIVO DE MELÃO IRRIGADO COM ÁGUAS SALINAS PROMOVE \\ ALTERAÇÕES QUÍMICAS EM ARGISSOLO
}

\begin{abstract}
Francisco Aécio Lima PEREIRA ${ }^{1}$; Hans Raj GHEYI ${ }^{2}$; José Francismar de MEDEIROS ${ }^{3}$; Nildo da Silva DIAS ${ }^{3, *}$; Cleyton dos Santos FERNANDES ${ }^{3}$; Rene Chipana RIVERA $^{4}$

1. Department of Science and Technology, Federal Rural University of the Semiarid Region, Caraúbas Campus, RN, Brazil; 2. Federal University of Recôncavo of Bahia, Cruz das Almas, BA, Brazil; 3. Department of Agricultural and Forestry Sciences, Federal Rural University of the Semiarid Region, Mossoró, RN, Brazil. *nildo@ufersa.edu.br; 4. Universidad Mayor de San Andrés, La Paz, Bolívia.
\end{abstract}

\begin{abstract}
The objective of the present study was to evaluate the salinization process and the changes in the chemical properties of an Acrisol cultivated with melon irrigated with water of different saline concentrations. The experiment was carried out in the field conditions using the experimental design of randomized blocks, arranged in split-plot. The plots were composed of salinity levels of irrigation water, expressed in terms of water electrical conductivity $\left(\mathrm{EC}_{\mathrm{w}}\right): 0.54 ; 1.48 ; 2.02 \mathrm{dS} \mathrm{m}^{-1}$; and the sub-plots for melon cultivars: Sancho and Medellín (Toad Skin), Mandacaru (Yellow), Nectar (Galia) and Sedna (Cantaloupe). Soil samples were collected at the beginning and end of the crop cycle to evaluate the changes in the physicalchemical properties of the soil. The electrical conductivity of saturation extract in the soil profile varied for each cultivar, observing high salinity values in soils with cultivars with lower water demand (Sedna and Nectar). The salinity of the soil was lower than the electrical conductivity of the irrigation water in the treatments with high values of $\mathrm{EC}_{\mathrm{w}}$. The soil $\mathrm{pH}$ values showed little reaction in relation to the initial values. The exchangeable sodium percentage values were approximate twice the sodium adsorption ratio of the saturation extract.
\end{abstract}

KEYWORDS: Cucumis melo L. Irrigated agriculture Salinization.

\section{INTRODUCTION}

The cultivation of melon (Cucumis melo L.) is a profitable crop with a fast-economic return. In Brazil, according to IBGE data (2019), in 2018, melon production reached 581,478 thousand tons, cultivated in an area of 23,324 hectares, with the Northeast region responsible for $92.87 \%$ of the national production and considered the main producing and exporting region of the country. The main exporting states in decreasing order are Ceará, Rio Grande do Norte, and Bahia.

Melon production in Rio Grande do Norte is concentrated in the micro-region of Mossoró, specifically in a region called Chapada do Apodi, covering the semiarid region near the coast. The main factors that favor the production and quality of melon fruits in that region are the proper soil and climate conditions (PEREIRA et al., 2017). Currently, in this producer pole, due to the low-cost of pumping of groundwater, it is common to substitute surface freshwater with saline waters from shallow wells of calcareous aquifers, which have high salt concentrations, often greater than $3.0 \mathrm{dS} \mathrm{m}$ 1 (SOUSA et al., 2009; DIAS et al., 2011; MEDEIROS et al., 2017).
The salts present in water can accumulate in the soil, reducing the development and production of crops. Aspect favored by various factors such as the reduction of the osmotic potential of the soil, toxic effects, and due to changes in the chemical and physical properties of the soil. Therefore, the sustainable use of saline waters in irrigation is conditioned to the management practices used in the water supply to the plants and fertilization, but mainly to the tolerance of the crop to salinity.

Many studies were carried out to quantify the effect of salts in the melon crop (ARAGÃO et al., 2009; GURGEL et al., 2010; FERNANDES et al., 2010), however, tolerance to salinity depends mainly on the concentration and type of salt present in the irrigation water, the time of exposure to salts and the way it comes in contact with the plant.

The accumulation process of salts in the soil is closely linked to the process of evapotranspiration since when the water in the soil is evapotranspired, the salts accumulate. The way in which the salts are transported and accumulated in the soil profile depends on the quantity and quality of the irrigation water and of the crop used, which may vary even between cultivars of the same species (TERCEIRO NETO et al., 2013). This, together with 
environmental factors such as evapotranspiration, crop rotation, and intensity and distribution of rainfall, promote the development of a characteristic saline profile for different regions and soil types (SILVA et al., 2008).

Therefore, the objective of this work was to evaluate the salinization and alterations of the chemical properties of an Acrisol cultivated with melon irrigated with saline water.

\section{MATERIAL AND METHODS}

The study was carried out at the Pedra Preta farm located in the municipality of Mossoró/RN ( $4^{\circ}$ $39^{\prime} 39^{\prime \prime} \mathrm{S}$ and $37^{\circ} 23^{\prime} 13^{\prime \prime} \mathrm{W}$, and altitude of $34 \mathrm{~m}$ ). The climatic classification of the zone according to Koeppen is of the BSwh' type, that is to say, hot and dry, characterized like a semiarid climate. According to Carmo Filho and Oliveira (1995), the climatic characteristics of the municipality are average temperature of $27.4{ }^{\circ} \mathrm{C}$, average annual rainfall of $673.9 \mathrm{~mm}$, and average relative humidity of $68.9 \%$.

The area of the experiment consisted of blocks $20 \mathrm{~m}$ wide and $30 \mathrm{~m}$ long, with four repetitions, totaling a useful area of 0.48 ha. The soil is classified as Acrisol Yellow, and it was prepared thirty days before the transplant, making a soft and subsoiling, opening of furrows, and construction of raised ridge. Soil samples were collected before the preparation of the land for chemical analysis. These analyses were carried out in the Irrigation and Salinity Laboratory of the Department of Environmental and Technological Sciences of the Federal Rural University of the Semi-arid UFERSA and in the Laboratory of Agricultural Engineering of the Federal University of Campina Grande - UFCG. Table 1 shows the physical- hydric and chemical analyzes of the soil.

Table 1. Physical-hydric and chemical characterization of the soil of the experimental area.

\begin{tabular}{|c|c|c|c|c|}
\hline \multirow{2}{*}{ Characteristics } & \multirow{2}{*}{ Units } & \multicolumn{3}{|c|}{ Depth (cm) } \\
\hline & & $0-15$ & 15-30 & $30-45$ \\
\hline Calcium & $\mathrm{cmol}_{\mathrm{c}} \mathrm{kg}^{-1}$ & 2.76 & 1.37 & 1.27 \\
\hline Magnesium & $\mathrm{cmol}_{\mathrm{c}} \mathrm{kg}^{-1}$ & 1.29 & 2.25 & 1.82 \\
\hline Sodium & $\mathrm{cmol}_{\mathrm{c}} \mathrm{kg}^{-1}$ & 0.15 & 0.10 & 0.10 \\
\hline Potassium & $\mathrm{cmol}_{\mathrm{c}} \mathrm{kg}^{-1}$ & 0.14 & 0.13 & 0.07 \\
\hline Hydrogen & $\mathrm{cmol}_{\mathrm{c}} \mathrm{kg}^{-1}$ & 0.00 & 0.00 & 0.00 \\
\hline Aluminum & $\mathrm{cmol}_{\mathrm{c}} \mathrm{kg}^{-1}$ & 0.00 & 0.00 & 0.00 \\
\hline CEC & $\mathrm{cmol}_{\mathrm{c}} \mathrm{kg}^{-1}$ & 4.34 & 3.85 & 3.36 \\
\hline Calcium carbonate & Qualitative & Absence & Absence & Absence \\
\hline Assimilable phosphorus & $\mathrm{mg} \mathrm{g}^{-1}$ & 5.08 & 5.07 & 5.06 \\
\hline $\mathrm{pH} \mathrm{H}_{2} \mathrm{O}_{(1: 2.5)}$ & - & 7.24 & 7.00 & 7.06 \\
\hline Saturation extract & Units & Value & & \\
\hline pHse & & 7.08 & 6.92 & 6.92 \\
\hline ECse & $\mathrm{dS} \mathrm{m}^{-1}$ & 0.94 & 0.85 & 0.46 \\
\hline Chloride & $\mathrm{mmol}_{\mathrm{c}} \mathrm{L}^{-1}$ & 3.50 & 3.75 & 2.00 \\
\hline Carbonate & $\mathrm{mmol}_{\mathrm{c}} \mathrm{L}^{-1}$ & 0.00 & 0.00 & 0.00 \\
\hline Bicarbonate & $\mathrm{mmol}_{\mathrm{c}} \mathrm{L}^{-1}$ & 4.00 & 4.00 & 2.40 \\
\hline Sulfate & $\mathrm{mmol}_{\mathrm{c}} \mathrm{L}^{-1}$ & Absence & Absence & Absence \\
\hline Calcium & $\mathrm{mmol}_{\mathrm{c}} \mathrm{L}^{-1}$ & 3.75 & 2.50 & 1.50 \\
\hline Magnesium & $\mathrm{mmol}_{\mathrm{c}} \mathrm{L}^{-1}$ & 6.37 & 7.50 & 3.87 \\
\hline Potassium & $\mathrm{mmol}_{\mathrm{c}} \mathrm{L}^{-1}$ & 0.69 & 0.69 & 0.35 \\
\hline Sodium & $\mathrm{mmol}_{\mathrm{c}} \mathrm{L}^{-1}$ & 3.84 & 3.94 & 2.74 \\
\hline SAR & $\left(\mathrm{mmol} \mathrm{L}^{-1}\right)^{0.5}$ & 1.67 & 1.76 & 1.67 \\
\hline Soil class & & Normal & & \\
\hline Physical Characteristics & Units & Value & & \\
\hline Sand & $\mathrm{g} \mathrm{kg}^{-1}$ & 935.8 & 925.6 & 875.50 \\
\hline Silte & $\mathrm{g} \mathrm{kg}^{-1}$ & 26.5 & 36.6 & 66.70 \\
\hline Clay & $\mathrm{g} \mathrm{kg}^{-1}$ & 37.7 & 37.8 & 57.80 \\
\hline Textural classification & & Sandy & Sandy & Sandy \\
\hline Bulk density & $\mathrm{g} \mathrm{cm}^{-3}$ & 1.48 & 1.48 & 1.47 \\
\hline Particle density & $\mathrm{g} \mathrm{cm}^{-3}$ & 2.69 & 2.72 & 2.73 \\
\hline Saturation percentage & $\%, \mathrm{~g} \mathrm{~g}^{-1}$ & 21.33 & 21.33 & 20.00 \\
\hline
\end{tabular}


Melon cultivation...

PEREIRA, F. A. L. et al.

\begin{tabular}{lllll} 
Porosity & $\%$ & 45.10 & 45.84 & 46.22 \\
Moisture at $33 \mathrm{kPa}$ & $\mathrm{g} \mathrm{kg}^{-1}$ & 60.60 & 72.80 & 87.60 \\
\hline
\end{tabular}

$\mathrm{CEC}=$ Cation exchange capacity; $\mathrm{pH} \mathrm{H}_{2} \mathrm{O}=$ Hydrogen potential in water; $\mathrm{pHes}=$ Hydrogenionic potential of the saturation extract; ECse = Electrical conductivity of the saturation extract; SAR = Sodium adsorption ratio.

The water supply to the area was carried out through two groundwater sources: the first one of calcareous origin, of low quality, extracted from calcareous sediments with tubular wells of $100 \mathrm{~m}$ depth, considered a flat well. The second one is from the Açu sandpit, which is located about 1,000 $\mathrm{m}$ deep, and its water is considered to be of excellent quality. Table 2 shows the results of the chemical analysis of the two water sources.

Table 2. Chemical analysis of the water used in the experiment.

\begin{tabular}{llll}
\hline \multirow{2}{*}{ Characteristics } & \multirow{2}{*}{ Units } & Groundwater source & \\
\cline { 3 - 4 } & & Sandpit Aquifer & Calcareous Aquifer \\
\hline $\mathrm{pH}$ & $\mathrm{dS} \mathrm{m}^{-1}$ & 0.50 & 6.90 \\
$\mathrm{EC}_{\mathrm{w}}$ & $\mathrm{mmol}_{\mathrm{c}} \mathrm{L}^{-1}$ & 1.60 & 3.90 \\
Chloride & $\mathrm{mmol}_{\mathrm{c}} \mathrm{L}^{-1}$ & 0.35 & 25.20 \\
Carbonate & $\mathrm{mmol}_{\mathrm{c}} \mathrm{L}^{-1}$ & 4.10 & 0.20 \\
Bicarbonate & $\mathrm{mmol}_{\mathrm{c}} \mathrm{L}^{-1}$ & $\mathrm{Absence}$ & 4.80 \\
Sulfate & $\mathrm{mmol}_{\mathrm{c}} \mathrm{L}^{-1}$ & 1.80 & Presence* \\
Calcium & $\mathrm{mmol}_{\mathrm{c}} \mathrm{L}^{-1}$ & 0.50 & 15.20 \\
Magnesium & $\mathrm{mmol}_{\mathrm{c}} \mathrm{L}^{-1}$ & 0.53 & 2.80 \\
Potassium & $\mathrm{mmol}_{\mathrm{c}} \mathrm{L}^{-1}$ & 0.79 & 0.15 \\
Sodium & $\left(\mathrm{mmol} \mathrm{L}^{-1}\right)^{0.5}$ & 0.74 & 19.00 \\
SAR & & 0.03 & 6.33 \\
\hline
\end{tabular}

$\mathrm{pH}=$ Hydrogen potential; $\mathrm{ECw}=$ Water electrical conductivity; $\mathrm{SAR}=$ Sodium adsorption ratio.

* Qualitative Analysis.

The treatments were the result of a combination of two factors: five levels of irrigation water salinity $\left(\mathrm{S}_{1}=0.54 ; \mathrm{S}_{2}=1.48 ; \mathrm{S}_{3}=2.02 ; \mathrm{S}_{4}=\right.$ $\left.3.03 \mathrm{e} \mathrm{S}_{5}=3.9 \mathrm{dS} \mathrm{m}^{-1}\right)$ and five melon cultivars $\left(\mathrm{C}_{1}=\right.$ Sancho "Pele de Sapo"; $\mathrm{C}_{2}=$ Medellín "Pele de Sapo"; $\mathrm{C}_{3}=$ Mandacaru "Amarelo"; $\mathrm{C}_{4}=$ Néctar "Gália"; $\mathrm{C}_{5}=$ Sedna "Cantaloupe"). The design experiment was of random blocks with divided plots $5 \times 5$ (salinity x cultivars) with 4 repetitions, totaling 100 experimental units. Saline concentrations were obtained by mixing the waters of the two sources (Table 1).

The drip irrigation system was used with polyethylene lateral lines and drippers fixed on the pipe wall. The main pipe was made of PVC of 32 $\mathrm{mm}$ diameter, the adductors of PVC of $50 \mathrm{~mm}$, and the connection of the lateral line with the tertiary line was made with a flexible polyethylene tube of $16 \mathrm{~mm}$. Both pipes were installed independently, one for each treatment, avoiding interference from one over the other. The spacing used was $2.0 \mathrm{~m}$ between lines and $0.30 \mathrm{~m}$ between emitters, with a nominal flow of the emitter of $1.35 \mathrm{~L} \mathrm{~h}^{-1}$ and coefficient of uniformity of emission of $94 \%$ for the area of work.

Irrigation management was carried out based on the climatic data of the meteorological station of the National Institute of Meteorology. Based on this information, the reference evapotranspiration (ETo) was determined by the Penmam-Monteih-FAO method (ALLEN et al., 2006), then the dual Kc was used to calculate the ETc.

The basal Kc used for the initial, intermediate (29 to 58 days) and final phases was $0.15,1.1$, and 0.7 , respectively. During the entire cycle, an irrigation water depth of $323.84 \mathrm{~mm}$ was applied for all treatments.

Before the implantation of the crop, a base superficial fertilization was carried out, recommended for the Pedra Preta farm, applying $420 \mathrm{~kg} \mathrm{ha}^{-1}$ of the commercial formula 6-24-12, that is, 25.2; 100.8 and $50.4 \mathrm{~kg} \mathrm{ha}^{-1}$ of $\mathrm{N}, \mathrm{P}_{2} \mathrm{O}_{5}$ and $\mathrm{K}_{2} \mathrm{O}$ $\mathrm{P} 2 \mathrm{O} 5$, respectively. Coverage fertilization was carried out by fertigation, based on soil analysis and recommendations made by Crisóstomo et al. (2002). During the crop cycle, the following amounts of nutrients were supplied: $81 ; 93$ and $188 \mathrm{~kg} \mathrm{ha}^{-1}$ of $\mathrm{N}$, $\mathrm{P}_{2} \mathrm{O}_{5}$, and $\mathrm{K}_{2} \mathrm{O}$, respectively. To complete the fertilization with micronutrients was carried out according to the phase and the nutrient need of the crop, in addition to the foliar application of micronutrients $\left(6.83 \mathrm{~L} \mathrm{ha}^{-1}\right.$ de $\mathrm{CaB} 2$ e $1.09 \mathrm{~L} \mathrm{ha}^{-1}$ Megafol). 
The nutrient solution with fertilizers was prepared using the water of lower salinity and later it was placed in a bypass tank with a capacity of 15 $\mathrm{L}$, which was injected into the pipe network before the control head. The amount of fertilizers applied by fertigation throughout the experiment were: potassium nitrate $\left(165.66 \mathrm{~kg} \mathrm{ha} \mathrm{ha}^{-1}\right)$, potassium chloride $\left(172.16 \mathrm{~kg} \mathrm{ha}^{-1}\right)$, sulfuric acid $(21.63 \mathrm{~kg} \mathrm{ha}$ $\left.\left.{ }^{1}\right)\right)$, MAP (111.51 kg ha $\left.{ }^{-1}\right)$, urea $\left(90.36 \mathrm{~kg} \mathrm{ha}^{-1}\right)$, nitric acid (43.25 $\left.\mathrm{L} \mathrm{ha}^{-1}\right)$, phosphoric acid $(35.6 \mathrm{~L}$ $\left.\mathrm{ha}^{-1}\right)$, boric acid (2.64 $\left.\mathrm{L} \mathrm{ha}^{-1}\right)$ and a commercial micronutrient compound (formulation $(\mathrm{w} / \mathrm{w})$ : B $0.65 \%$, $\mathrm{Cu} 0.28 \%$, Fe 7.5\%, Mn 3.5\%, Mo 0, 30, Zn, $0.70 \%$ and $\mathrm{S} 7.5 \%)\left(11.54 \mathrm{~kg} \mathrm{ha}^{-1}\right)$.

During the cultivation cycle, the plantation lines were covered with a layer of polyethylene (mulching) with black and white faces, to reduce phytosanitary problems in the fruits and optimize the use of water, avoiding evaporation and partly controlling the weeds.

To evaluate the soil characteristics, samples were collected at the end of the cycle, with the help of a $0.03 \mathrm{~m}$ diameter shank hole. In each subplot, soil samples were taken from three layers $(0-15,15-$ 30 and $30-45 \mathrm{~cm}$ ), in three points equidistant to 10 $\mathrm{cm}$ from the neck of the plants, taking two plants per experimental unit, in such a way that have two samples in the direction of the row of the plantation (one before and another after the plant), and another on the opposite side of the lateral line, forming a $90^{\circ}$ angle with the neck of the plant, i.e. in the form of a triangle, forming a composite sample of six points per depth in the experimental unit.

The composite samples were air-dried, breaking up clods and sieved in a $0.002 \mathrm{~m}$ mesh, where the electrical conductivity was determined according to the methodology proposed by EMBRAPA (1999). The determination of the electrical conductivity of the saturation extract (ECse), was developed from the equation obtained by the methodology of the reduced main axis, according to Menk and Igue (1992), from the $\mathrm{EC}_{1: 2.5}$ versus the ECse of the composite samples of each experimental unit, considering each depth.

The parameters used in the evaluation of soil salinity were: the $\mathrm{pH}$, the electrical conductivity of the saturation extract (ECse) and the Sodium Adsorption Ratio (RAS) obtained through Eq. 1, in addition to the sodification of the soil that is calculated by the Exchangeable Sodium Percentage (ESP), obtained through Eq. 2.

$$
S A R=\frac{\mathrm{Na}^{+}}{\sqrt{\frac{\mathrm{Ca^{+ } + M g ^ { + }}}{2}}}
$$

Where:

1) $)^{1 / 2}$.

SAR $=$ Sodium Adsorption Ratio $\left(\mathrm{mmol} \mathrm{L}^{-}\right.$

$$
\mathrm{Ca}^{2+}=\text { Calcium concentration in the water }
$$
of the saturation extract $\left(\mathrm{mmol}_{\mathrm{c}} \mathrm{L}^{-1}\right)$.

$\mathrm{Mg}^{2+}=$ Magnesium concentration in the water of the saturation extract $\left(\mathrm{mmol}_{\mathrm{c}} \mathrm{L}^{-1}\right)$.

$\mathrm{Na}^{+}=$Sodium concentration in the water of the saturation extract $\left(\mathrm{mmol}_{\mathrm{c}} \mathrm{L}^{-1}\right)$.

$$
E S P=\frac{N a^{+}}{C E C} x 100
$$

Where:

$\left(\mathrm{mmol}_{\mathrm{c}} \mathrm{kg}^{-1}\right)$.

ESP $=$ Exchangeable Sodium Percentage.

$\mathrm{Na}^{+}=$Exchangeable or adsorbed Sodium

CEC = Cation Exchange Capacity of the soil or the sum of the exchangeable cations $(\mathrm{Ca}, \mathrm{Mg}$, $\mathrm{Na}, \mathrm{K}, \mathrm{Al}$, and $\mathrm{H})\left(\mathrm{mmol}_{\mathrm{c}} \mathrm{kg}^{-1}\right)$.

With the obtained data, an analysis of variance and regression was made, using the software SAEG V. 9.0 (RIBEIRO JUNIOR, 2001). Regression models were selected based on the significance of the regression coefficients at the 5\% probability level, through the F test and the highest value of the determination coefficient (r).

\section{RESULTS AND DISCUSSION}

The results obtained from the relationship between $\mathrm{EC}_{1: 2.5}$ and the ECse show that there is a linear effect with a high degree of correlation for the three soil layers and similar relationships for the variation of the concentration factor that varies from 7.42 to 8,16 , reaching the average value for the profile at 7,86 (Figure 1). As the results were satisfactory for the three layers of soil and quite close, only an equation with the average values of the profile was used, which was enough to do the correlation, transforming the $\mathrm{EC}_{1: 2.5}$ values to the ECse. Results similar to those obtained in this study were found by Medeiros et al. (2017) when evaluating the salinity and $\mathrm{pH}$ of an Acrisol irrigated with saline waters under different management strategies. 


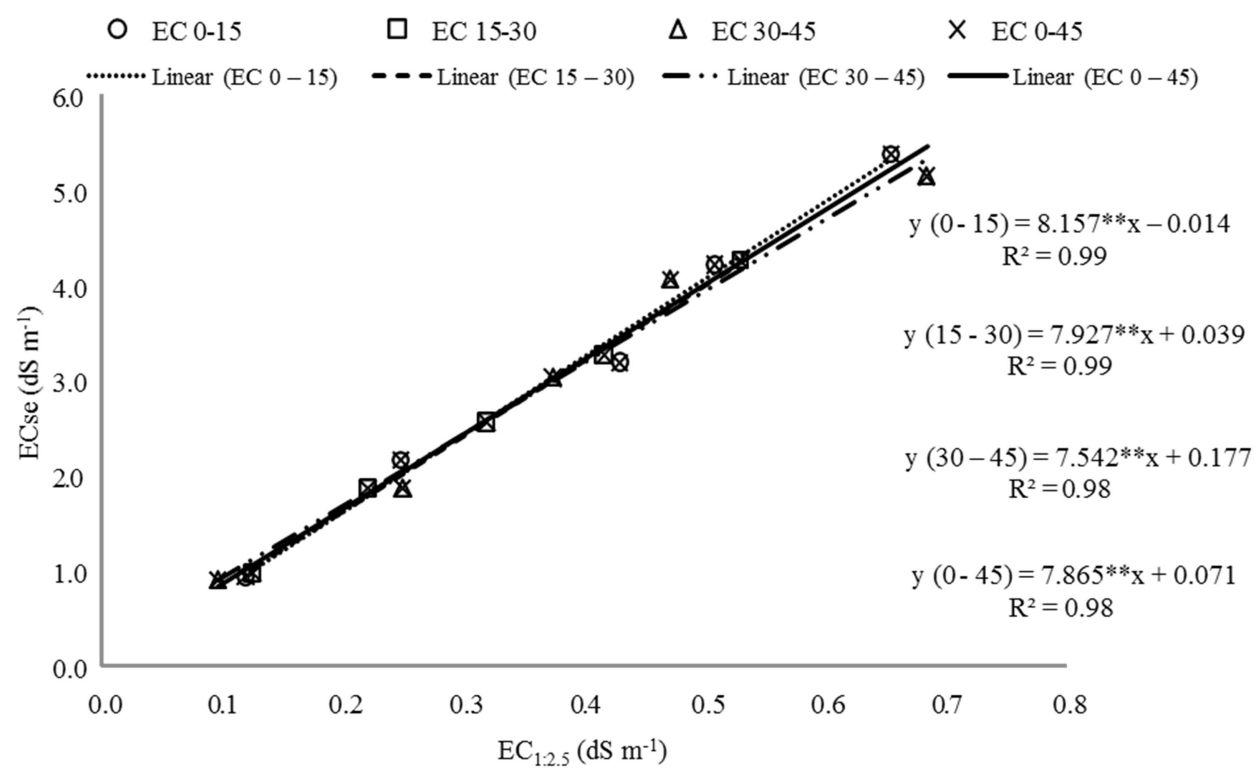

Figure 1. Relationship between $\mathrm{EC}_{1: 2.5}$ and $\mathrm{ECse}$ at the end of the experiment.

Equation parameters $(* *)$ significant at 0.01 according to the $\mathrm{F}$ test.

Figure 2 shows the average values of the electrical conductivity of the soil saturation extract (ECse) of the profile corresponding to the root zone of each cultivar (average of the three evaluated layers), at the end of the cycle. It can be noticed that for all the cultivars, there is an increase of the salinity of the soil with the increase of the salinity of the irrigation water, however, with different tendencies among cultivars. This elevation occurred due to the higher salt content of the irrigation waters with higher EC. As the ECse is directly proportional to the accumulation of soil salts, which, in turn, is directly proportional to the salinity of the irrigation water. Therefore, the greater the salinity of the water, the higher the saline concentration of the soil, as indicated by Porto Filho et al. (2011). It can be seen that the ECse values were above the $\mathrm{EC}_{\mathrm{w}}$ only for the salinity level $\mathrm{S}_{1}\left(0.54 \mathrm{dS} \mathrm{m}^{-1}\right)$; in the case of salinity $\mathrm{S}_{2}\left(1.48 \mathrm{dS} \mathrm{m}^{-1}\right)$ similarity of the ECse and $\mathrm{EC}_{\mathrm{w}}$ values occurred, except for the Nectar and Sedna cultivars, which showed higher ECse from the salinity level of $S_{1}$ compared to the other cultivars.

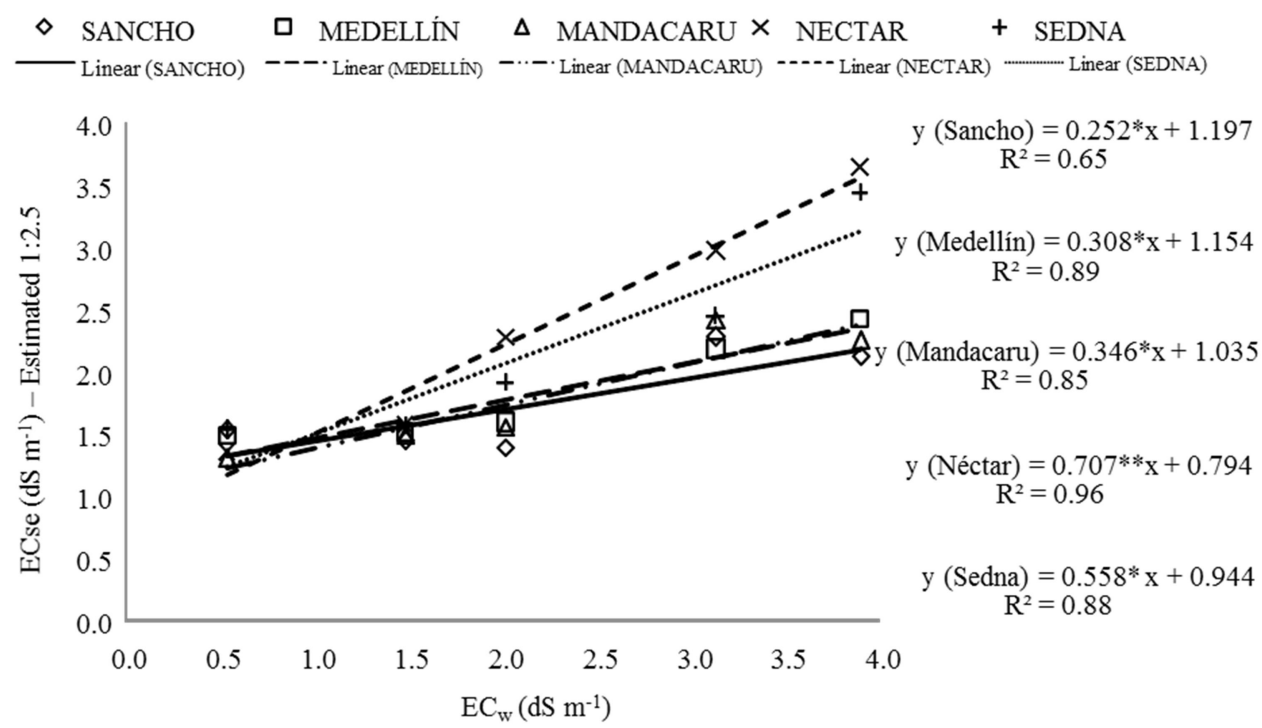

Figure 2. Relationship between average ECse of the soil profile $(0-45 \mathrm{~cm})$ and for the root zone of melon cultivars irrigated with water of different salinity levels.

$(* *)$ significant at $0.01 ;(*)$ significant at 0.05 and (ns), according to the $\mathrm{F}$ test. 
Generally, crops irrigated with high salinity water tend to decrease the ECse at the end of the cycle, compared to the period of greatest water demand for the crop. In this study, it was observed that at the end of the cycle of the cultivars, the treatments that were irrigated with water of better quality $\left(0.54 \mathrm{dS} \mathrm{m}^{-1}\right)$, presented similar values of electrical conductivity of the saturation extract for all the cultivars, and about 2.7 times more than the irrigation water. This value was possibly increased due to the initial salinity of the soil (average profile of $0.75 \mathrm{dS} \mathrm{m}^{-1}$ - Table 2) and the salinity resulting from fertilizer applications. However, for the treatment that had the highest salinity level (3.90 dS $\left.\mathrm{m}^{-1}\right)$, the conductivity of the saturation extract was about $30 \%$ lower than that of the irrigation water, with an average value of $2.78 \mathrm{dS} . \mathrm{m}^{-1}$. Porto Filho et al. (2011) when working with yellow melon cultivars and similar salinity levels observed that the average salinity in the soil profile at the end of the cycle was higher than the salinity of the irrigation water, but mulching was not used in the work cited.

From the salinity level $\mathrm{S}_{3}\left(2.02 \mathrm{dS} \mathrm{m}^{-1}\right)$, the ECse of the cultivars Sancho, Medellín, and Mandacaru were far below the concentration of the $\mathrm{EC}_{\mathrm{w}}$ and for the cultivars Nectar and Sedna the tendency of the salinity of the saturation extract was close to the $\mathrm{EC}_{\mathrm{w}}$. Possibly because these cultivars showed a lower vigor, and so a lower water consumption, and that the humidity in excess caused that the calcareous water, rich in bicarbonate, reacted with calcium $(\mathrm{Ca})$ in the soil, precipitating it and raising the salinity with the $\mathrm{NaCl}$ present in the water of higher salinity (Table 1). However, it is observed that these values are much lower than that found in the literature, a fact attributed to the high leaching of the soil, which has a sandy characteristic, reaching $85 \%$ of sand in the profile from 0 to $45 \mathrm{~cm}$ (Table 2) and by the use of mulching. According to Ayers and Westcot (1999), in a conventional sprinkler irrigation system, the average salinity of the ECse is about 1.5 times the EC value of the irrigation water, considering a leaching fraction of 15 to $20 \%$ in equilibrium conditions.

In addition to the factors indicated above, at the end of the cycle a rainfall of $15 \mathrm{~mm}$ occurred, part of which was drained in the hole where the plants were transplanted, leaching part of the salts near the area where the soil samples were collected. This leaching could have been significant since the soil was at field capacity. According to Medeiros et al. (2017), another justification is that the monitored soil was in the part closest to the center of the wetbulb (radius of $10 \mathrm{~cm}$ ), in addition to the mulching, which by eliminating evaporation from the soil surface decreases the accumulation of salts in the superficial layer, among other factors. Lower salinity values can also be justified by the fact that it was measured at the end of the cycle, where normally the values are lower than in the middle of the crop cycle. For Ayers and Westcot (1999) the salinity of the soil depends on the quality of the irrigation water, edaphoclimatic factors, and irrigation management.

Figure 3 shows the $\mathrm{pH}$ values of the soil profiles corresponding to layer 0 to $45 \mathrm{~cm}$, at the end of the cycle for each melon cultivar and water electrical conductivity. It is observed that there was a small variation between the initial $\mathrm{pH}$ of the soil (Table 2) and the final $\mathrm{pH}$ in each treatment, as well as between the treatments. It can also be noticed that in the layers of 15 to 30 and 30 to $45 \mathrm{~cm}$ the $\mathrm{pH}$ values had an insignificant increase, independently of the salinity, raising the $\mathrm{pH}$ of 7.00 and 7.06 to 7.17 and 7.10 , respectively, being similar to the results found by Porto Filho et al. (2011) who when working with four levels of salinity, varying from 0.6 to $4.5 \mathrm{dS} \mathrm{m}^{-1}$, in two successive experiments in the same experimental area, they verified a great uniformity in the values. 

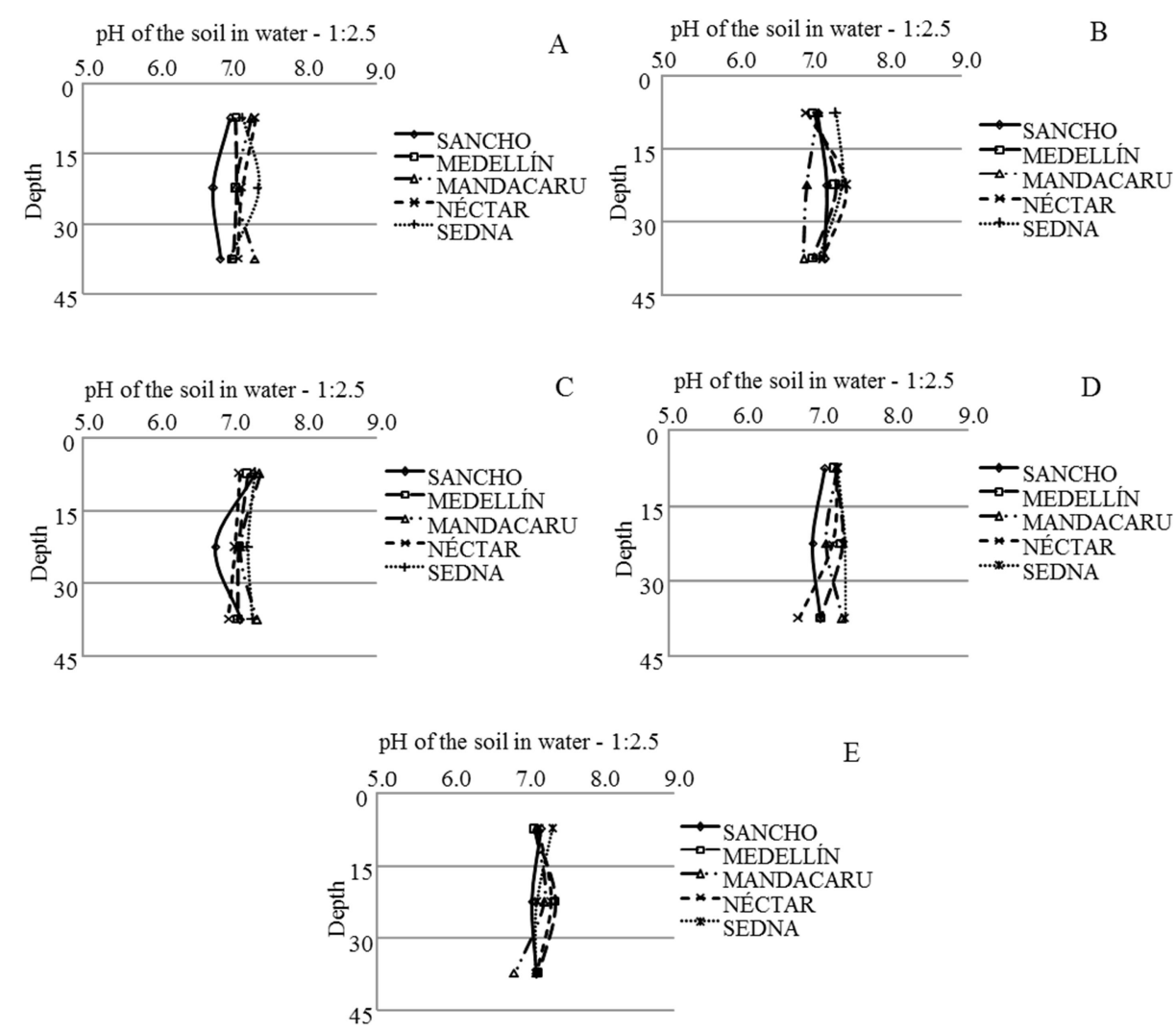

Figure 3. Average $\mathrm{pH}$ values $(1: 2.5)$ in the soil profile at the end of the cycle of the melon cultivars irrigated with water of different salinity levels.

A - Salinity $\mathrm{S}_{1}\left(0.54 \mathrm{dS} \mathrm{m}^{-1}\right) ;$ B - Salinity $\mathrm{S}_{2}\left(1.48 \mathrm{dS} \mathrm{m}^{-1}\right) ; C$ - Salinity $\mathrm{S}_{3}\left(2.02 \mathrm{dS} \mathrm{m}^{-1}\right) ; \mathrm{D}$ - Salinity $\mathrm{S}_{4}\left(3.03 \mathrm{dS} \mathrm{m}^{-1}\right) ; \mathrm{E}$ Salinity $\mathrm{S}_{5}\left(3.90 \mathrm{dS} \mathrm{m}^{-1}\right)$.

For the layer of $0-15 \mathrm{~cm}$, the average values were close to the initial value, both for the water of lower and for the highest salinity. The values at the end of the cycle varied between 7.00 and 7.50. For the $\mathrm{pH}$ in the radicular profile of the cultivars, the values varied between 7.12 and 7.19 , verifying a small variation, which indicates that the cultivar does not interfere in the $\mathrm{pH}$ of the soil. That elevation of the $\mathrm{pH}$ in the layer of 15 to $45 \mathrm{~cm}$ is a result of the irrigation water itself since its $\mathrm{pH}$ a is equal to or greater than 6.90 (Table 1) and by the chemical fertilization with nutrients based on salts soluble directly applied in the irrigation water, that with the course of the cycle the salts move towards the deepest layers, raising the $\mathrm{pH}$ in the reached zone.

Paiva et al. (2004) when studying waters of salinity between 1.2 to $4.4 \mathrm{dS} \mathrm{m}^{-1}$, found high values of the $\mathrm{pH}$ from the $20 \mathrm{~cm}$ of depth, elevating the $\mathrm{pH}$ from 6.47 to 6.87 . In studies conducted by Silva et al. (2007) to verify the risks of salinization in four soil types, with salinity levels that varied from 0 to 3 $\mathrm{dS} \mathrm{m}^{-1}$, observed a small increase in $\mathrm{pH}$ at the beginning, but showed a tendency to stabilize when the values were next to neutrality.

The sodium adsorption ratio (SAR) increased proportionally to the $\mathrm{EC}_{\mathrm{w}}$ values (Figure 4 ), independently of the cultivar. The range of variation of the observed results of the SAR was 2.4 to $5.6\left(\mathrm{mmol} \mathrm{L}^{-1}\right)^{0.5}$ which indicates that almost all values are within the class of slight to moderate restriction (AYERS; WESTCOT, 1999). The SAR values of the irrigation waters used ranged from 0.7 to $6.3\left(\mathrm{mmol} \mathrm{L}^{-1}\right)^{0.5}$ corresponding to $\mathrm{S}_{1}$ and $\mathrm{S}_{5}$, respectively. 


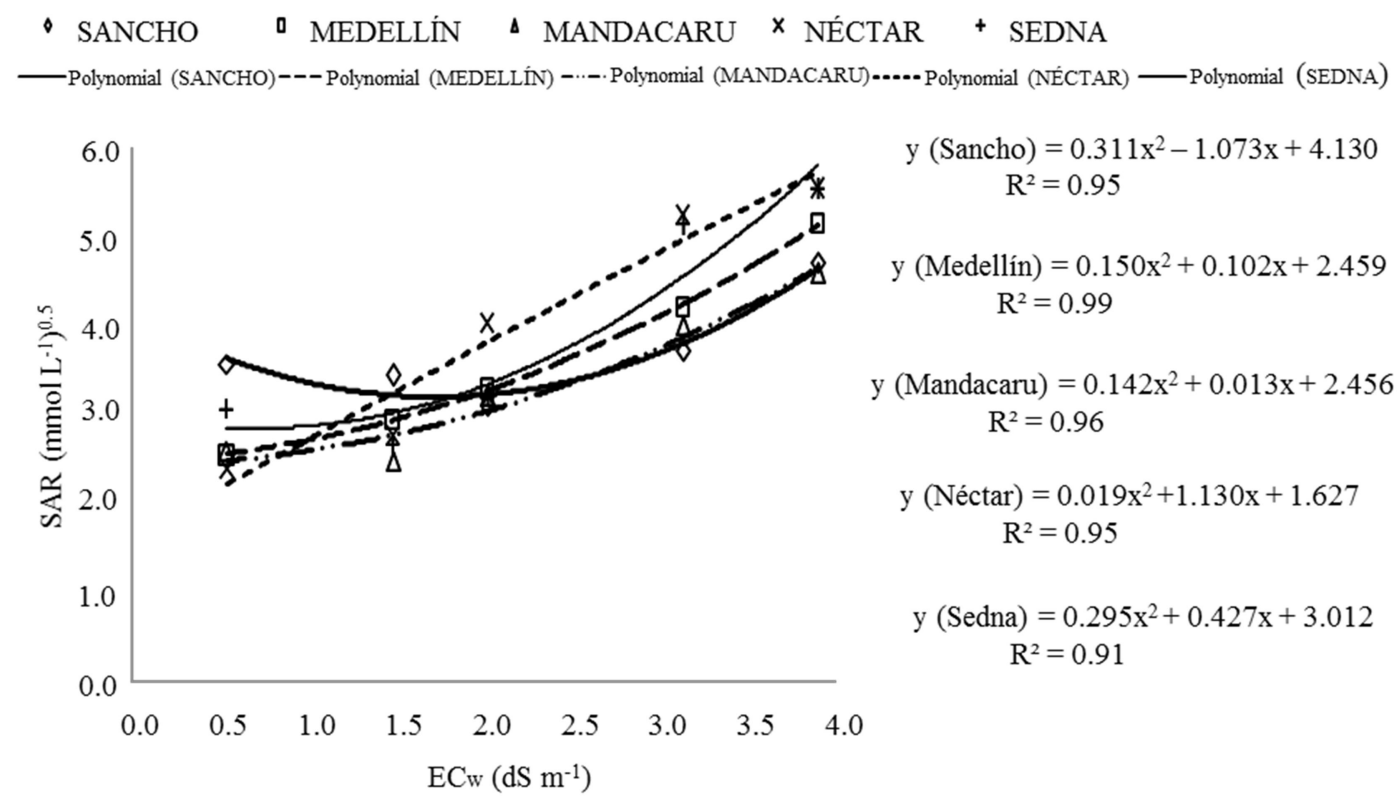

Figure 4. Relationship between SAR in the root profile $(0-45 \mathrm{~cm})$ and $\mathrm{EC}_{\mathrm{w}}$, after harvesting of melon cultivars irrigated with water of different levels of salinity.

The SAR values for irrigation water of lower and higher salinity were 0.74 and 6.33, respectively, and the estimated values of the SAR of treatments $\mathrm{S}_{2}, \mathrm{~S}_{3}$, and $\mathrm{S}_{4}$ were $3.22 ; 4.10$ and 5.41, respectively. Comparing the $\mathrm{SAR}_{\mathrm{es}}$ with the $\mathrm{SAR}$ of the irrigation water, a similar behavior with the $\mathrm{EC}_{\mathrm{w}}$ and ECse was observed, being that the values of the $\mathrm{SAR}_{\mathrm{es}}$ for the lowest level of salinity were maintained higher than that of the irrigation water. For $\mathrm{S}_{2}$, an equilibrium was found with the $\mathrm{SAR}_{\mathrm{es}}$ and for values above $S_{3}$, it was verified that the value of the $\mathrm{SAR}_{\mathrm{es}}$ was below the SAR of the waters used in the treatments.

The tendency in the increase of the SAR is clearer from the level of salinity $\mathrm{S}_{3}\left(3.03 \mathrm{dS} \mathrm{m}^{-1}\right)$. Probably, this tendency occurs due to the reaction of $\mathrm{Ca}^{2+}$ with bicarbonate, causing $\mathrm{Ca}^{2+}$ to precipitate. With this, the sodium present tends to increase its relative concentration (Table 1), causing the elevation of the SAR, since it is directly proportional to the sodium concentration, which agrees with the data of Silva et al. (2007), who verified that with the increase in salinity there was an increase in the SAR in the four types of soil evaluated. Unlike the others, the cultivar Sancho had a small reduction in the SAR up to the salinity level $\mathrm{S}_{3}\left(3.03 \mathrm{dS} \mathrm{m}^{-1}\right)$ and from there, followed the trend of the others.

When an adjustment was made between the SAR and the ECse (Figure 5), a good correlation was obtained, even higher than that obtained with the EC of the irrigation water, being independent of the cultivars. This is justified by the fact that the composition of the waters is proportional, since the levels $\mathrm{S}_{2}, \mathrm{~S}_{3}$, and $\mathrm{S}_{4}$ were obtained by mixing extreme EC waters.

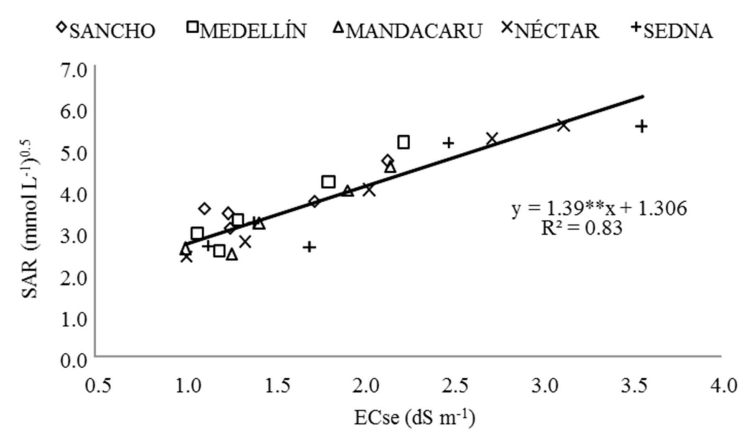

Figure 5. Relationship between SAR and ECse of the root profile $(0-45 \mathrm{~cm})$ of melon cultivars irrigated with water of different salinity levels.

Equation parameters $(* *)$ significant at 0.01 according to test $\mathrm{F}$. 
The ESP values did not correlate with the $\mathrm{EC}_{\mathrm{w}}$, but there was an average correlation between the ESP and the ECse (Figure 6). All the ESP values found were below 15\% and according to Richards' classification (1954), both values are classified as non-sodic, that is, soils without sodic problems. Analyzing the ECse, it was verified that all the results of the analyzes gave values lower than $4 \mathrm{dS}$ $\mathrm{m}^{-1}$, therefore, the soil in none of the treatments is classified as saline.

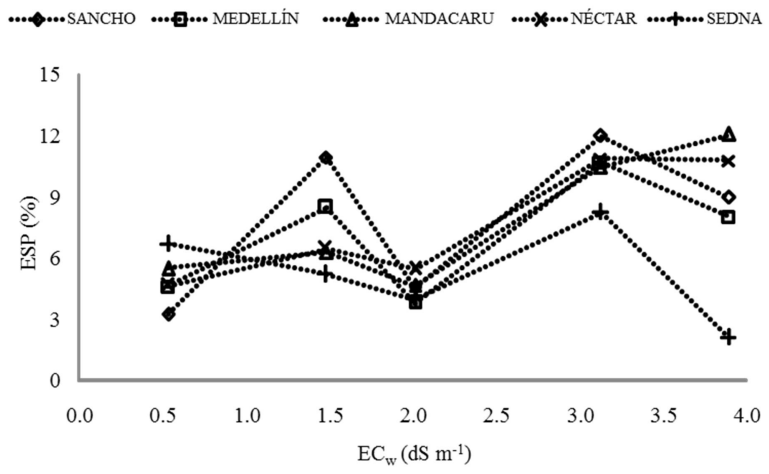

Figure 6. Exchangeable sodium percentage (ESP) of the soil observed as a function of $\mathrm{EC}_{\mathrm{w}}$ for the root profile $(0-45 \mathrm{~cm})$ of melon cultivars irrigated with water of different salinity levels.

Some more judicious authors adopt ECse values of $2 \mathrm{dS} \mathrm{m}^{-1}$ and $\mathrm{ESP}>7$ as a limit for salinity and sodicity problems. In this case, between 32 and $44 \%$ of the analyzes would be with values above the least limit for the ECse and ESP, respectively
(Figure 7). For sensitive crops up to moderately tolerant to salinity, such as melon, these values can cause a reduction in production, according to Ayres $\&$ Westcot (1999) since it has a threshold salinity of $2.2 \mathrm{dS} \mathrm{m}^{-1}$.

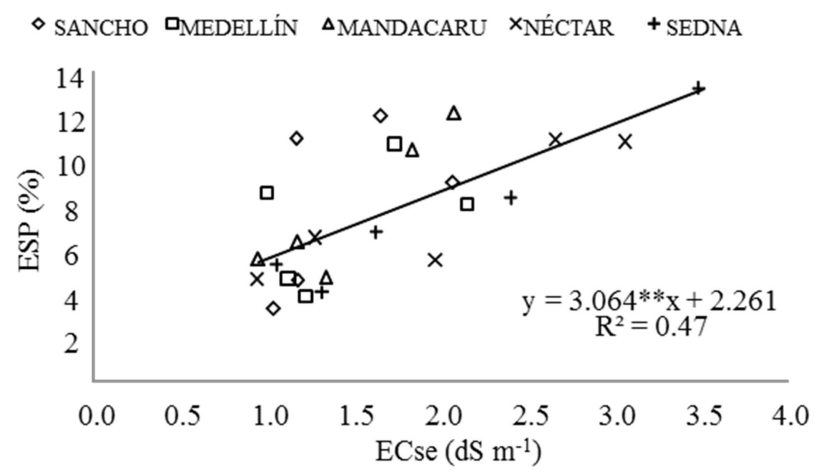

Figure 7. Relationship between ESP and ECse for the root profile $(0-45 \mathrm{~cm})$ of melon cultivars irrigated with water of different salinity levels.

Equation parameters $(* *)$ significant at 0.01 .

\section{CONCLUSIONS}

The relationship between the ECse and the $\mathrm{EC}_{\mathrm{w}}$ was reduced in the profile of soils with cultivars with lower water demand (Sedna and Nectar).
The $\mathrm{pH}$ of the soil did not change at the end of the irrigation application cycle with saline water.

Soil salinity values (ECse) were lower than those of irrigation water $\left(\mathrm{EC}_{\mathrm{w}}\right)$ for high salinity levels.

RESUMO: O objetivo do presente estudo foi avaliar o processo de salinização e as alterações dos atributos químicos de um Argissolo cultivado com melão irrigado com água de diferentes concentrações salinas. O experimento foi desenvolvido em campo aberto utilizando o delineamento de blocos casualizados em parcelas subdividas. As parcelas constituíram de níveis de salinidade da água de irrigação, expressa em condutividade elétrica da água $\left(\mathrm{CE}_{\mathrm{a}}\right): 0,54 ; 1,48 ; 2,02 ; 3,03$ e $3,90 \mathrm{dS} \mathrm{m}^{-1}$ e, as sub-parcelas de cultivares de 
melão: Sancho e Medellín (Pele de Sapo), Mandacaru (Amarelo), Néctar (Gália) e Sedna (Cantaloupe). Amostras de solos foram coletadas no início e no final do ciclo da cultura para avaliação do processo de salinização e das alterações dos atributos físico-químicos do solo. Os resultados mostraram que a ECse no perfil do solo variou para cada cultivar, sendo as maiores salinidades observadas nos solos cultivados com as cultivares que utilizam uma menor demanda hídrica (Sedna e Néctar). A salinidade do solo foi sempre inferior ao da condutividade elétrica da água de irrigação nos tratamentos com maiores $\mathrm{CE}_{\mathrm{a}}$. Os valores de $\mathrm{pH}$ do solo apresentaram pequena reação em relação aos valores iniciais. Os valores de porcentagem de sódio trocável foram cerca de duas vezes superiores ao da razão de adsorção de sódio do estrato de saturação.

PALAVRAS CHAVES: Agricultura irrigada. Cucumis melo L. Salinização.

\section{REFERENCES}

ALLEN, R. G.; PEREIRA, L. S.; RAES, D.; SMITH, M. Evapotranspiración del cultivo, Guías para la determinación de los requerimientos de agua de los cultivos. Rome: FAO, 2006. 322 p.

ARAGÃO, C. A.; SANTOS, J. S.; QUEIROZ, S. O. P.; DANTAS, B. F. Avaliação de cultivares de melão sob condições de estresse salino. Revista Caatinga, Mossoró, v. 22, n. 2, p. 161-169, 2009.

AYERS, R. S.; WESTCOT, D. W. A qualidade da água na agricultura. Campina Grande: UFPB, 1999. 153 p.

CARMO FILHO, F.; OLIVEIRA, O. F. Mossoró: Um município do semiárido nordestino, caracterização climática e aspecto florístico. Mossoró: ESAM, 1995. 62 p.

CRISÓSTOMO, L. A.; SANTOS, A. A.; FARIA, C. M. B.; SILVA, D. J.; FERNANDES, F. A. M.; SANTOS, F. J. S.; FREITAS, J. A. D.; HOLANDA, J. S.; CARDOSO, J. W.; COSTA, N. D. Adubação, irrigação, híbridos e práticas culturais para meloeiro no Nordeste. Fortaleza: Embrapa Agroindústria Tropical, 2002. $22 \mathrm{p}$.

DIAS, N. S.; OLIVEIRA, A. M.; SOUSA NETO, O. N.; BLANCO, F. F.; REBOUÇAS, J. R. L. Concentração salina e fases de exposição à salinidade do meloeiro cultivado em substrato de fibra de coco. Revista Brasileira de Fruticultura, Jaboticabal, v. 33, n. 3, p. 915-921, 2011. https://doi.org/10.1590/S0100$\underline{29452011005000084}$

EMBRAPA. Centro Nacional de Pesquisa de Solos. Sistema Brasileiro de Classificação de Solos. Brasília: EMBRAPA, 1999. 412 p.

FERNANDES, O. B.; PEREIRA, F. E. F.; ANDRADE JÚNIOR, W. P. DE; QUEIROGA, R. C. F.; QUEIROGA, F. M. Efeito do nitrato de cálcio na redução do estresse salino no meloeiro. Revista Caatinga, Mossoró, v. 23, n. 3, p. 93-103, 2010.

GURGEL, M. T.; UYEDA, C. A.; GHEYI, H. R.; OLIVEIRA, F. H. T. DE; FERNANDES, P. D.; SILVA, F. V. Crescimento de meloeiro sob estresse salino e doses de potássio. Revista Brasileira de Engenharia Agrícola e Ambiental, Campina Grande, v. 14, n. 1, p. 3-10, 2010. https://doi.org/10.1590/S1415$\underline{43662010000100001}$

INSTITUTO BRASILEIRO DE GEOGRAFIA E ESTATÍSTICA (IBGE). Disponível em: $<$ htpp://www.ibge.gov.br>. Acesso em: 30 jan. 2018.

MEDEIROS, J. F.; TERCEIRO NETO, C. P. C.; DIAS, N. S.; GHEYI, H. R.; SILVA, M. V. T.; LOIOLA, A. T. Salinidade e $\mathrm{pH}$ de um Argissolo irrigado com água salina sob estratégias de manejo. Revista Brasileira de Agricultura Irrigada, Fortaleza, v. 11, n. 3, p. 1407 - 1419, 2017. https://doi.org/10.7127/rbai.v11n300560 
MENK, J. R. F.; IGUE, T. Relacionamento de dados entre métodos analíticos: o caso da análise granulométrica. Revista Brasileira de Ciência do Solo, Viçosa, v. 16, n. 2, p. 143-152, 1992.

PAIVA, A. S.; MEDEIROS, J. F.; CASTRO, M. C. S.; ALVES, L. P.; SARMENTO, D, H.; SILVA JÚNIOR, M. J. Salinidade e reação do solo numa área cultivada com melão sob mulch e irrigado com água de diferentes níveis de sais. Revista Caatinga, Mossoró, v. 17, n.2, p. 57-63, 2004.

PEREIRA, F. A. L.; MEDEIROS, J. F.; GHEYI, H. R.; DIAS, N. S.; PRESTON, W.; VASCONCELOS, C. B. L. Tolerance of melon cultivars to irrigation water salinity. Revista Brasileira de Engenharia Agrícola e Ambiental, Campina Grande, v.21, n.12, p. 846-851, 2017. https://doi.org/10.1590/18071929/agriambi.v21n12p846-851

PORTO FILHO, F. Q.; MEDEIROS, J. F.; GHEYI, H. R.; DIAS, N. S.; SOUSA, P. S.; DANTAS, D. C. Evolução da salinidade e pH de solo sob cultivo de melão irrigado com água salina. Revista Brasileira de Engenharia Agrícola e Ambiental, Campina Grande, v. 15, n. 11 p. 1130-1137, 2011. https://doi.org/10.1590/S1415-43662011001100004

RIBEIRO JUNIOR, J. I. Análises estatísticas no SAEG. Viçosa: Folha de Viçosa, 2001. 301 p.

RICHARDS, L. A. Diagnosis and improvement of saline and alkali soils. Washington: United States Department of Agriculture, 1954. $160 \mathrm{p}$.

SILVA, M. O.; FREIRE, M. B. G. S.; MENDES, A. M. S.; FREIRE, F. J.; DUDA, G. P.; SOUSA, C. E. S. Risco de salinização em quatro solos do Rio Grande do Norte sob irrigação com águas salinas. Revista Brasileira de Ciências Agrárias, Recife, v. 2, n.1, p. 8-14, 2007. https://doi.org/10.5039/agraria.v2i1a1917

SILVA, O. M.; FREIRE, M. B. G. S.; MENDES, A. M. S.; FREIRE, F. J.; SOUZA, C. E. S.; GÓIS, G. B. Crescimento de meloeiro e acúmulo de nutrientes na planta sob irrigação com águas salinas. Revista Brasileira de Engenharia Agrícola e Ambiental, Campina Grande, v. 12, n. 6, p. 593-605, 2008.

https://doi.org/10.1590/S1415-43662008000600005

SOUSA, R. B. C.; OLIVEIRA, L. M.; DIAS, N. S.; CARVALHO, J. W. C.; GURGEL, M. T. Variação sazonal das águas subterrâneas utilizadas para irrigação na microrregião de Tibau, RN. Revista Caatinga, Mossoró, v. 22, n. 4, p. 206-213, 2009.

TERCEIRO NETO, C. P. C.; GHEYI, H. R.; MEDEIROS, J. F.; DIAS, N. S.; CAMPOS, M. S. Produtividade e qualidade de melão sob manejo com água de salinidade crescente. Pesquisa Agropecuária Tropical, Goiânia, v. 43, n. 4, p. 354-362, 2013. https://doi.org/10.1590/S1983-40632013000400007 